Przegląd Badań Edukacyjnych Educational Studies Review

ISSN 1895-4308

nr 25 (2/2017), s. 59-74

METAANALIZY

BADAŃ

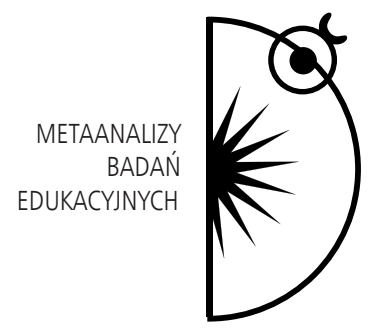

Uniwersytet Warmińsko-Mazurski w Olsztynie, e-mail: mzaorska@poczta.onet.pl

\title{
Kultura, kulturowość, sztuka oraz wiek kulturowy i rozwój kulturowy dziecka w świetle poglądów Lwa S. Wygotskiego
}

DOI: http://dx.doi.org/10.12775/PBE.2017.019

\section{Culture, Culturalism Art and Cultural Age and Cultural Development of the Child in the Light of Leo S. Vygotski's Views}

\begin{abstract}
The issue of cultural development, cultural development, perception of art, which is part of human cultural development, is an important issue in the field of possible theoretical analyzes and related practical activities. One of the psychological concepts in which reflections on signaled relationships are present is the concept proposed by the Russian psychologist L.S. Vygotsky. Therefore, the purpose of this article is to point out the selected theses from the views of the learned scientist on the broadly understood issue of cultural development of human beings in connection with the historical and cultural development of humanity as well as factors determining that development.
\end{abstract}

Keywords: culture, art, cultural development, cultural development, L.S. Vygotsky on the development of human culture.

\section{Wprowadzenie}

Problematyka rozwoju kulturowego, rozwoju kulturalnego, percepcji powiązanej w sygnalizowanymi elementami rozwoju, sztuki znajduje swoje odzwierciedlenie i przełożenie nie tylko w rozważaniach stricte teoretycznych, ale rów- 
nież w działaniach związanych z praktyką życia osobistego konkretnych ludzi i zbiorowości, do których ludzie przynależą. Począwszy od okresu starożytności wielu znakomitych myślicieli tego okresu (np. Sokrates, Arystoteles, Cyceron), jak i następujących po nich, zajmowało zarówno zagadnienia terminologiczne, definicyjne, jak i wpisujące się w nie uwarunkowania rozwoju kulturowego i kulturalnego konkretnych jednostek i społeczeństw. Ponadto interesowano się zagadnieniem recepcji dorobku historyczno-kulturowego pokoleń minionych przez pokolenia kolejne.

Swoistym połączeniem tematyki powiązań pomiędzy rozwojem historyczno-kulturowym ludzkości a rozwojem psychospołecznym (w tym też kulturowym i kulturalnym) człowieka jest koncepcja zaproponowana przez psychologa rosyjskiego Lwa S. Wygotskiego, która łączy wskazane elementy oraz podejmuje autorską próbę ich zidentyfikowania, zrozumienia, przełożenia na rozwój psychiczny, społeczny i indywidualny człowieka, w korelacji z rozwojem grupy społecznej, do której on przynależy i przekazanym w czasie wychowania (i kształcenia) dorobkiem cywilizacyjnym.

Dlatego też w treści niniejszego opracowania została podjęta próba opisania poglądów L.S. Wygotskiego na temat rozwoju kulturowego, kulturalnego i sztukę, biorąc pod uwagę wybrane tezy i możliwą ich interpretację. Zanim jednak sygnalizowane poglądy zostaną wskazane, stosownym wydaje się zdefiniowanie istotnych dla realizowanego dyskursu terminów w percepcji współczesnych badaczy danej problematyki.

\section{Dyskurs terminologiczny}

Termin „kultura” (od łac. cultura, ae - uprawa, kształcenie) - w pierwotnej interpretacji, zaproponowanej przez Marka Tuliusza Cycerona, to moralne i intelektualne wykształcenie jednostki, podnoszące ją na wyższy poziom człowieczeństwa. Od wieku XVIII termin kultura przybierał znaczenie ucywilizowania społeczeństwa (jako przeciwstawne np. dzikości), szczególnie w zakresie obyczajów, prawa, stosunków politycznych, nauki (i w odróżnieniu od sfery materialno-technicznej - określanej pojęciem „cywilizacja”). Z upływem czasu, i za przyczyną narastającej świadomości zróżnicowania społeczeństw, rozumienia trudności w wartościowaniu ich organizacji, wierzeń, tradycji - w wieku XX kształtuje się uniwersalne pojęcie kultury, odnoszące się do historycznego dorobku duchowego, politycznego i materialnego dowolnego społeczeństwa (dawnego albo współczesnego), lub jego części (np. określonej grupy społecznej, robotników, chłopów), czy też w ogólności, lub pod jakimś względem 
(np. kultura filozoficzna, literacka). Cechą współczesnej kultury, ze względu na neutralność samego pojęcia ,jest to, że pomimo neutralności i opisowości (wyrażającej się w dążności do nieporównywania kultur pod względem wartości) zachowała pozytywny znaczeniowo odcień, postulujący równość i wartościowość wszystkich kultur. Kultura stanowi również ten element, który różnicuje świat ludzki i przyrody - przez kulturę bowiem rozumie się świat ludzki w oderwaniu od przyrody otaczającej człowieka" (Hartman, 2004, s. 123).

Kultura w obszarze aktywności twórczej ludzi - za słownikami języka polskiego - to termin oznaczający: 1) całokształt materialnego i duchowego dorobku ludzkości, wytworzonego w ogólnym rozwoju historycznym lub w jego określonej epoce; poziom rozwoju społeczeństw, grup, jednostek w danej grupie społecznej; 2) stopień doskonałości, sprawności w opanowaniu jakiejś umiejętności (np. rozwoju intelektualnego, moralnego, sposobu bycia); 3) kulturę fizyczną - część składową kultury społeczeństwa, obejmującą dziedzinę kształtowania fizycznych uzdolnień człowieka, naukę (Tokarski, 1978, s. 407).

Kulturowy natomiast to związany z kulturą, z całokształtem dorobku materialnego i duchowego ludzkości (Tokarski, 1978, s. 735). Pojęcie filozofia kultury z kolei interpretowane jest jako badanie warunków, pochodzenia, sensu i celu kultury, jej dziejów i form. Teorie kultury powstawały sukcesywnie od XVIII wieku, np. teoria J.J. Rousseau dotycząca krytycznych aspektów kultury czy teoria kulturowego pesymizmu F. Nietzschego. Włącza między innymi zagadnienia kręgów kulturowych, relacje organizmu z kulturą (Aduszkiewicz, 2004, s. 175). Zasadniczo jednak filozofia kultury to dział filozofii, ogół współczesnych dociekań filozoficznych dotyczących człowieka jako twórcy kultury: obyczaju, prawa, państwa, wiary, sztuki, wiedzy, cywilizacji materialnej. Obejmuje kwestie różnorodności i przejawów jedności treści kulturowych na przestrzeni dziejów i w różnych regionach świata. Filozofia kultury, ze względu na różnorodność i pewne uszczegółowianie analizy zagadnienia kultury współpracuje z antropologią kulturową, historią, etnologią, literaturoznawstwem, hermeneutyką, fenomenologią i wieloma innymi dyscyplinami wiedzy (Hartman, 2004, s. 73).

Określenie sztuka (gr. téchne, łac. ars) może być definiowane w co najmniej trzech aspektach: 1) jako umiejętność, dyspozycja umysłowa twórcy, 2) jako czynność wytwórcza, 3) jako wytwór, dzieło sztuki. Samo pojęcie sztuki było różnie pojmowane w różnych epokach historycznych. W starożytności sztuka była rozumiana jako wszelka działalność metodyczna, tj. oparta na określonych regułach.. Wszystkie umiejętność w tym czasie klasyfikowano na mechaniczne (wymagające wysiłku fizycznego) i wolne (np. retoryka, astronomia, matematyka, muzyka). Pojęcie sztuk pięknych nie istniało. Wyodrębniło 
się stopniowo, dzięki rozwojowi malarstwa w epoce odrodzenia, aczkolwiek dopiero w wieku XVIII pojawiało się i rozpowszechniło pojęcie sztuk pięknych jako przyporządkowanych realizacji wartości estetycznych i zaspokajaniu estetycznych potrzeb ludzi (Tatarkiewicz 2011, s. 21-54). Zmianie uległo także rozumienie sztuki. To już nie tylko i tyle starożytne naśladowanie, odtwarzanie kształtu czy czynności twórczych kogoś innego, ale przede wszystkim ekspresja, tj. wyrażanie własnych przeżyć artysty. W następnych epokach sztuka awangardowa całkowicie odrzuciła jakiekolwiek przyporządkowanie tradycyjnym wartościom estetycznym. Instytucjonalna teoria sztuki stoi na stanowisku, że dowolny przedmiot może stać się dziełem sztuki w zależności od kontekstu, w jakim się znajduje (np. w galerii, muzeum), albo od czysto subiektywnego uznania go za dzieło. Sztuką może być więc nie tylko samo dzieło, ale czynność artysty, albo jego pomysł, wymagający jedynie zakomunikowania, bez żadnej dalszej realizacji tegoż pomysłu (sztuka konceptualna). Naczelną wartością tak rozumianej sztuki staje się nowość i zaszokowanie widza, słuchacza. Sztuką mogą być realizacje nietrwałe, nienastawione na transfer w przyszłość (Hartman, 2004, s. 220-221).

Sztuka, za słownikami języka polskiego, ujmowana jest w konwencji: 1) twórczości artystycznej, obejmującej dzieła z zakresu malarstwa, architektury, rzeźby, muzyki, literatury odpowiadające wymogom estetyki, odznaczające się pięknem i harmonią, 2) umiejętność, biegłość w wykonywaniu czegoś, talent i kunszt, mistrzostwo, 3) czynność, działanie będące wyrazem czyjejś zręczności, umiejętności, sprytu (Tokarski, 1978, s. 735).

Określenie tworzyć zaś oznacza: powodować powstanie czegoś (Tokarski, 1978, s. 802). Określenie twórczy - inaczej tworzący, mający zdolność tworzenia, związany z tworzeniem (s. 803). Pojęcie dzieło - to wytwór o znacznej wartości artystycznej, znaczący z uwagi na jego nowatorstwo, wkład w rozwój jakiejś dziedziny nauki, życia społecznego, w rozwój ludzkości: malarskie, muzyczne, literackie, naukowe (Doroszewski, 1980, s. 143).

\section{Lew S. Wygotski - nota biograficzna}

Lew S. Wygotski ${ }^{1}$ (1896-1934) to jeden z najwybitniejszych psychologów XX wieku. Działalność i dorobek naukowy tego znakomitego uczonego wniosły

${ }^{1}$ Biografię L.S. Wygotskiego opisano w oparciu o artykuł: Zaorska M. (2008). Lew S. Wygotski o wychowaniu dzieci głuchoniewidomych, Człowiek - Niepelnosprawność - Społeczeństwo, nr 2(8), APS, Warszawa, s. 7-16. 
znacząc wkład w rozwój psychologii ogólnej, rozwojowej, klinicznej, specjalnej, psychologii sztuki.

Wygotski urodził się 17 listopada (tj. 5 listopada według kalendarza gregoriańskiego) 1896 roku w miejscowości Orsza na Białorusi. Wkrótce rodzice przeprowadzili się do miasta Homel. Od klasy czwartej szkoły podstawowej naukę szkolną kontynuował w środowisku domowym, a po zdaniu tzw. egzaminu eksternistycznego z materiału obowiązującego w klasie piątej, podjął edukację w szóstej klasie gimnazjum dla chłopców. Szczególnie interesował się matematyką, literaturą, filozofią oraz językami obcymi. W szkole uczył się języka niemieckiego i francuskiego, a w warunkach rodzinnych dodatkowo języka łacińskiego, greckiego i angielskiego.

W 1913 roku Wygotski skończył gimnazjum i rozpoczął studia na Wydziale Medycznym Uniwersytetu Moskiewskiego. Jednak po kilku tygodniach przeniósł się na Wydział Prawa. Od roku 1914 - równolegle ze studiami prawniczymi - studiował na Wydziale Historyczno-Filozoficznym w Państwowym Uniwersytecie im. Szaniawskiego. Będąc studentem opublikował pierwsze prace naukowe z zakresu literatury. W 1917 roku ukończył dwie wskazane uczelnie, łącząc w latach 1916-1917 edukację akademicką z pracą na stanowisku sekretarza redakcji czasopisma „Nowa Droga”.

Wiedza z historii, filozofii, literatury zdobyta przez Wygotskiego w czasie studiów wpłynęła na krystalizowanie się jego zainteresowań naukowych, w szczególności psychologią oraz jej wybranymi subdyscyplinami. Po studiach wrócił do Homela i podjął pracę jako nauczyciel literatury w tzw. szkole pracy. Prowadził zajęcia ze słuchaczami studiów nauczycielskich, studiów wychowawców placówek przedszkolnych z przedmiotów: logika i psychologia, a w konserwatorium $-\mathrm{z}$ estetyki i historii sztuki. W tym też czasie w lokalnej prasie publikuje artykuły oraz recenzje o tematyce literackiej i teatralnej. Kieruje działalnością teatru skupiającego aktorów niezawodowych. Występuje z wykładami otwartymi na temat twórczości wybitnych pisarzy i poetów. Organizuje tzw. spotkania poniedziałkowe, w których uczestniczą znani intelektualiści zamieszkujący Homel. Z inicjatywy Wygotskiego wydawane jest w tym mieście literackie czasopismo „Wrzos”.

W 1919 roku zachorował na gruźlicę. Mimo choroby kontynuuje aktywną działalność naukową, organizacyjną i praktyczną. W opisywanym okresie krystalizują się zainteresowania psychologią. Przy Liceum Pedagogicznym zorganizował Laboratorium Psychologiczne, w którym prowadził badania diagnostyczne dzieci w normie rozwojowej oraz dzieci z niepełnosprawnością 
z zastosowaniem metody G.I. Rossolimo. ${ }^{2}$ Wyniki zrealizowanych badań naukowych zaprezentował w wystąpieniu na zjeździe z zakresu psychoneurologii, który odbył się w Sankt Petersburgu (Pietrogrodzie) w roku 1924. Dzięki temu wystąpieniu otrzymał propozycję pracy w Moskwie, w Instytucie Psychologii Eksperymentalnej. W roku 1924 przeniósł się do Moskwy. Wkrótce po zdaniu egzaminów zawodowych uzyskał status pracownika naukowego.

W roku 1925 ożenił się z Różą Smiechową. W tym też roku przyszła na świat pierwsza córka - Gita, a w roku 1930 druga córka - Asia. Od roku 1924 prowadził badania nad zagadnieniami świadomości, relacji psychologii i filozofii, współczesnych poglądów psychologicznych na temat rozwoju człowieka, psychologii wychowawczej i klinicznej. Ze szczególną uwagą odnosił się do zagadnienia niepełnosprawności, a także wybranych jej typów. W latach 1924-1934 koncentrował się na tych właśnie zagadnieniach.

Z rekomendacji organizatora Eksperymentalnego Instytutu Defektologii I.I. Daniuszewskiego, w roku 1924, zostaje kierownikiem Wydziału Wychowania Dzieci z Niepełnosprawnością Fizyczną i Intelektualną, funkcjonującego przy Wydziale Socjalno-Prawnej Obrony Niepełnoletnich Ministerstwa Edukacji. Ten moment uważany jest za początkujący działalność uczonego w dziedzinie psychologii klinicznej.

W roku 1925 uczestniczył w międzynarodowym kongresie na temat wychowania dzieci z wadą słuchu w Anglii, w czasie którego przedstawił referat na temat metod nauczania uczniów niesłyszących oraz roli czynników socjo-kulturowych i socjo-kulturowego kontekstu wychowania człowieka w procesie jego adaptacji społecznej. Ponadto w roku 1925 Wygotski odbył inne podróże zagraniczne: do Niemiec, Holandii, Francji. Celem było poznanie organizacji kształcenia osób niepełnosprawnych. Po powrocie z zagranicy ciężko choruje z powodu nawrotu gruźlicy. Aż przez rok przebywał na zwolnieniu lekarskim. Nie przerwał jednak swojej aktywności naukowej. Dopracował książkę pt. Psychologia sztuki, którą opublikowano dopiero 40 lat później.

W 1925 roku Wygotskiemu wyznaczono datę publicznej obrony pracy habilitacyjnej, do której, ze względu na chorobę, nie mógł przystąpić. Dlatego decyzją komisji habilitacyjnej zostaje zwolniony z publicznej obrony rozprawy habilitacyjnej i zaocznie uzyskuje status samodzielnego pracownika naukowe-

${ }^{2}$ G.I. Rossolimo (1860-1928), neurolog rosyjski; w roku 1899 opisał jedną z odmian zapalenia nerwu, w roku 1902 głęboki odruch palcowy, objaw uszkodzenie dróg piramidowych; cyt. za: R. Dzierżanowski, Stownik chronologiczny dziejów medycyny i farmacji, PZWL, Warszawa 1983, s. 476. 
go. W październiku 1925 roku zdobywa stopień docenta na Wydziale Pedagogiki, Psychologii i Defektologii 2-go Państwowego Uniwersytetu w Moskwie (aktualnie Moskiewski Państwowy Uniwersytet Pedagogiczny; w danej uczelni pracował w latach 1924-1934). W tym czasie, na pół roku, przerywa pracę przyczyną jest ponowne pogorszenie stanu zdrowia. Przebywając na zwolnieniu lekarskim przygotowuje monografię Sens historyczny kryzysu w psychologii oraz liczne artykuły na temat koncepcji psychoanalitycznych. W domu Wygotskiego spotykają się inni wybitni uczeni, np.: A.N. Leontiew i A.R. Luria.

W roku 1926 zorganizował Laboratorium Psychologii Defektologicznej przy Instytucie Neurologicznym, prowadził badania nad diagnozą możliwości rozwojowych dzieci z niepełnosprawnością. W roku 1929, na bazie wspomnianego laboratorium, powołano Eksperymentalny Instytut Defektologii Ministerstwa Edukacji. Wygotski zostaje konsultantem ds. naukowych. Pracując w tym Instytucie koncentruje swoje badania naukowe na zagadnieniach kompensacji i nadkompensacji u osób z niepełnosprawnością, konsekwencji utraty sprawnych funkcji u osób nabywających niepełnosprawność w późniejszym okresie życia. Analizuje problematykę roli doświadczenia wyniesionego z relacji społecznych i interakcji komunikacyjnych z innymi ludźmi w rozwoju dziecka, zarówno pełno- jak i niepełnosprawnego. Podkreśla istnienie identycznych praw rządzących rozwojem dzieci pełno- i niepełnosprawnych, tendencji ogólnych i specyficznych w ich rozwoju. Do specyficznych tendencji włącza: odmienność doświadczeń historyczno-kulturowych oraz społecznych. Istota nauczania i wychowania dzieci z niepełnosprawnością zadaniem uczonego polega na uwzględnieniu specyfiki rozwoju dziecka, która zależy od rodzaju uszkodzeń, które to uszkodzenia w różny sposób i w różnym stopniu wpływają na pozyskiwanie oraz gromadzenie doświadczeń życiowych. Artykułuje tezę, że: „Człowiek w każdym momencie swojego istnienia dysponuje ogromnymi, jeszcze nieujawnionymi możliwościami i potencjałami” (Ulotka: 120-ta rocznica urodzin Lwa Siemionowicza Wygotskiego, MPGU, Moskwa 2016, s. 4). Krytykuje propozycje i obecne w praktyce wychowawczej osób z niepełnosprawnością tendencje mechanicznego trenowania, wielokrotnego powtarzania czynności niezbędnych dzieciom niepełnosprawnym w ich życiu w oparciu o specjalne ćwiczenia. Postuluje potrzebę organizacji działań rehabilitacyjnych i edukacyjnych na bazie aktywizacji dziecka poprzez zabawę, naukę, pracę, relacje z innymi ludźmi. Omawiając zależności istniejące pomiędzy nauczaniem i rozwojem zwraca uwagę na fakt, że nauczanie powinno wyprzedzać w czasie rozwój dziecka, na koniczność uwzględniania/uwzględnienia aktualnego poziomu rozwoju (sfera aktualnego rozwoju) i rozwoju potencjalnego (sfera najbliższego rozwo- 
ju). Sferę najbliższego rozwoju, zdaniem Wygotskiego, należy identyfikować biorąc pod uwagę możliwości wykonywania przez dziecko bardziej skomplikowanych zadań, także zadań możliwych do realizacji z pomocą ze strony osób starszych. Ocena możliwości dziecka w sferze najbliższego rozwoju powinna odbywać się na bazie analizy otwartości dziecka na przyjmowanie okazywanej pomocy i perspektywie wykonywania podobnych zadań w przyszłości samodzielnie. Sygnalizowana koncepcja Wygotskiego powstała nie tylko w oparciu o doświadczenia praktyczne, badania naukowe oraz analizę literatury źródłowej, ale także krytykę tendencji do dokonywania pomiarów rozwoju poprzez testowanie dziecka. Wygotski nie przekreśla jednak możliwości częściowego testowania w działaniach diagnostycznych.

W latach 30-tych XX wieku koncentruje się na zagadnieniach psychopatologii, przede wszystkim na kwestiach: rozwoju myślenia, rozpadu wyższych funkcji psychicznych przy uszkodzeniach mózgu (w tym mowy, pamięci, np. u osób z afazją, schizofrenią, chorobą Parkinsona). Pracując nad wymienionymi problemami uświadamia sobie potrzebę uzupełnienia swojego wykształcenia o kompetencje z zakresu medycyny. Dlatego, w roku 1931, podejmuje studia na Wydziale Medycznym Instytutu Psychoneurologii w Charkowie (będąc już profesorem i uznanym autorytetem w dziedzinie psychologii). Jednak z powodu obowiązków zawodowych (badania eksperymentalne, przygotowywanie publikacji, praca dydaktyczna, wystąpienia na konferencjach, zjazdach, seminariach, działalność organizacyjna) nie zdołał skończyć studiów medycznych. Nie przeszkadzało to jednak podjęciu, w roku 1934, funkcji kierownika Oddziału Psychologii w Instytucie Medycyny Eksperymentalnej. Na kilka miesięcy przed śmiercią kończy książkę pt. Myślenie i mowa (1989), którą opublikowano już po śmierci autora.

Wiosną 1934 roku pogorsza się stan zdrowia uczonego. Mimo zaleceń lekarskich o potrzebie hospitalizacji kontynuuje aktywne życie zawodowe. Umiera w nocy z 10 na 11 czerwca 1934 roku. Ostatnie słowa Wygotskiego brzmiały następująco: „Jestem przygotowany” (w kontekście: na śmierć). Oficjalny pogrzeb Wygotskiego (po kremacji) odbył się dopiero w roku 1935.

Naukowe zasługi Wygotskiego można ulokować w poznaniu następujących obszarów psychologii: 1) koncepcja działalności ludzkiej; 2) kulturowo-historyczna istota psychiki; 3) znaczenie aktywności/działalności społecznej i grup społecznych w rozwoju psychicznym człowieka; 4) koncepcja sfer rozwoju; 5) psychologiczne podstawy nauczania nacelowanego na rozwój i uwzględniającego współpracę pomiędzy podmiotami biorącymi udział w tym procesie; 6) osobowość jako integralna struktura; 7) psychologia kliniczna i pedagogika 
korekcyjna - rozwój osoby z niepełnosprawnością w oparciu o jej możliwości, zasoby, a nie objawiane konsekwencje negatywne (Leontiew, 2003).

Pod adresem naukowców Wygotski skierował następującą słowa: „Niech myśleniu odważnych uczonych przyświeca teza: należy dążyć do poznania i wyjaśnienia niewiadomych. Ostrożnym i mądrze przeciwstawiającym się tym odważnym - poznania niewiadomych na obecnych faktach. Dążność do wyjaśnienia wszystkiego i czasami niemożliwego do wyjaśnienia oznacza brak jakiegokolwiek wyjaśnienia" (Ulotka: 120-ta rocznica urodzin Lwa Siemionowicza Wygotskiego, MPGU, Moskwa 2016, s. 4; cyt. za: L.S. Wygotski, Psychologia rozwoju człowieka).

\section{Kultura, kulturowość, sztuka w wizji, percepcji, poglądach Lwa S. Wygotskiego}

W pracach poświęconych problematyce kultury, kulturowego rozwoju ludzkości i człowieka Wygotski stoi na stanowisku, że sztuka jest społeczną techniką odczuwania tego, co uznajemy, że posiada wartość artystyczną (1980, s. 43), a szczególnie estetyczną. Dzieło artystyczne, zdaniem uczonego, jest całokształtem sposobów i środków estetycznych dążących do wywołania wzruszeń, emocji, których źródło tkwi nie tyle w duchowości, duchowej organizacji osoby, ile w interpretacji znaków i/lub znaczeń nadawanych sztuce przez daną osobę, które to znaczenia uzyskuje ona poprzez przyswajanie historyczno-cywilizacyjnego dorobku ludzkości (1980, s. 43-44). Źródła estetyki nie tyle leżą w naturze duszy osoby czy w metafizyce, ile w symbolice społecznej, uwarunkowaniach socjologicznych i historycznych. Sztukę określa i warunkuje bowiem psychika człowieka społecznego (społeczna psychika osoby). Psychikę człowieka społecznego zaś konstruują następujące elementy: 1) stan sił wytwórczych społeczeństwa; 2) uwarunkowane za przyczyną tych sił stosunki ekonomiczne; 3) ustrój społeczno-polityczny, który powstał na danej podstawie ekonomicznej, 4) psychika człowieka społecznego; 5) różne ideologie odzwierciedlające właściwości tej psychiki (1980, s. 52).

Badacz percypuje sztukę jako szczególną formę ideologii, która odnosi się do tej specyficznej i wyjątkowej sfery ludzkiej psychiki. Sztukę, spośród wszystkich innych form ideologii wyróżnia to, że przy jej analizie musi być zastosowana analiza psychologiczna. Sztuka porządkuje swoiście i w swoisty sobie sposób sferę psychiki człowieka, którą są jego uczucia. I mimo, że u podstaw wszelkich sfer psychiki człowieka leżą te same przyczyny sprawcze, to działają one poprzez różne procesy psychiczne, powodując różnorodne formy 
ideologii (1980, s. 54-55). Wygotski (1980, s. 57) pisze: „Gdybyśmy zdali sobie trud i wyliczyli, co w konkretnych dziełach literackich stworzyli sami ich autorzy, a co zaczerpnęli w stanie gotowym $\mathrm{z}$ istniejącej tradycji literackiej, to doszlibyśmy do wniosku, że elementem ściśle własnym w ich twórczości jest zaledwie wybór tych lub innych czynników, ich konwencji, przenoszenie pewnych tradycyjnych elementów do innych systemów"..

Analizę zagadnienia oddziaływania sztuki na człowieka, w opinii Wygotskiego (1980, s. 58-59), może ułatwić zarówno podejście proponowane przez psychologię społeczną - koncentrujące się na psychice jednostki, psychologię dyferencyjną - jej zadanie polega na badaniu indywidualnych różnic pomiędzy poszczególnymi osobami oraz psychologię zbiorową - charakteryzuje poglądy całych grup społecznych .

W analizie przeżyć estetycznych proponuje metodę introspekcji, biorącą pod uwagę specyfikę i odrębność indywidualnych, subiektywnych przeżyć ludzi. Jak twierdzi Wygotski (s. 59): „Przeżycie estetyczne z natury pozostaje niezrozumiałe i ukryte przed podmiotem $w$ istocie swej i przebiegu. Nigdy nie wiemy i nie zrozumiemy, dlaczego spodobało się nam to lub inne dzieło. Wszystko, co wykoncypujemy, by wytłumaczyć jego oddziaływanie, jest dorabiane ex post i stanowi jawną racjonalizację nieuświadamianych procesów. Sama zaś istota przeżycia nadal pozostaje dla nas zagadką. Sztuka na tym właśnie polega, by ukryć sztukę." (mając na myśli ukrycie sztuki przez nami i przed sobą samą, tzn. ukrycie sztuki przed sztuką)..

„Bez specjalnej analizy psychologicznej nigdy nie zrozumiemy - zdaniem L.S. Wygotskiego (s. 61), jakie prawa rządzą emocjonalnym oddziaływaniem dzieła artystycznego, i za każdym razem ryzykujemy popełnieniem bardzo poważnego błędu. Należy przy tym zaznaczyć, że i socjologiczne badania sztuki nie są w stanie wyjaśnić do końca mechanizmu oddziaływania utworu artystycznego na ludzi i zbiorowości ludzkie"..Psychologiczne ujęcie problematyki sztuki można bardziej trafnie wyjaśnić nie ekonomiczną genezą sztuki, lecz genezą sensu jej oddziaływania i znaczenia uroku sztuki, który nie pozostaje W sprzeczności ze stopniem rozwoju społecznego, na jakim to sztuka wyrosła (s. 63-64). Nie znaczy to w żadnym razie, że warunki społeczne częściowo tylko czy nie w pełnej mierze określają charakter i oddziaływanie dzieła artystycznego, ale że określają je pośrednio. Same uczucia, które wywołuje dzieło artystyczne są uczuciami uwarunkowanymi społecznie (s. 64). Stąd, formułując jakiekolwiek psychologiczne prawa oddziaływania sztuki na człowieka (jeśli w ogóle jest to możliwe), jesteśmy zmuszeni do poszukiwania, identyfikacji i zinterpretowania powiązań oraz prawidłowości istniejących w życiu społecz- 
nym z prawidłowościami oddziaływania sztuki na ludzi, ponieważ dokonują się one zawsze w korelacji ze wszystkimi pozostałymi formami ich działalności ludzkich. Wobec powyższego słusznym wydaje się, że psychologia społeczna może i powinna stworzyć punkt oparcia do badania sztuki. Jednakże równocześnie powinno się zróżnicować i oddzielić problematykę psychologiczną od socjologicznej (s. 65-66).

Na podstawie opisanych założeń Wygotski postuluje, że najwłaściwszym w działaniach dotyczących analizy procesów i generalnie rzecz ujmując wszelkich zagadnień związanych z oddziaływaniem sztuki na ludzi jest odwołanie do psychologii pojedynczego człowieka. Przeżycia pojedynczego człowieka bowiem mieszczą się w przedmiocie analiz realizowanych przez psychologię społeczną, gdyż przeżycia estetyczne ludzi i grup społecznych posiadają uwarunkowania społeczne. Dlatego w opinii uczonego psychologia sztuki powinna nie tyle i nie tylko koncentrować się na badaniu i poznawaniu przeżyć autora dzieła, artysty czy odbiorcy jego wytworu, ile na samym dziele sztuki, korzystając ze świadectwa przekazywanego przez odbiorcę sztuki (1980, s. 67-68). W ramach przedstawionej interpretacji każde dzieło sztuki powinno być traktowane jako system bodźców zorganizowanych świadomie w celu wywołania reakcji estetycznej. Analizując strukturę bodźców odtwarzamy strukturę reakcji - są to reakcje obiektywne, bezosobowe, nienależące do konkretnego człowieka. Wskazane podejście pozwala na ustalenie natury reakcji estetycznych w czystym kształcie, bez wpływu procesów przypadkowych. Reakcji estetycznej przebiegającej na kontinuum: od formy działa artystycznego - poprzez analizę funkcjonalną jej elementów i struktury - do odtworzenia reakcji estetycznej i ustalenia jej praw ogólnych (s. 68-69).

Zdaniem Wygotskiego (1980, s. 124), dopóki analizy psychologiczne będą ograniczać się jedynie do procesów przebiegających w ludzkiej świadomości, dopóty nie zostanie udzielona odpowiedź na najbardziej podstawowe pytanie psychologii sztuki, tzn. odpowiedź na pytanie o istotę przeżyć estetycznych, o istotę tworzenia i odbioru sztuki . Autor nie popiera oraz krytykuje pogląd, że bezpośrednie przyczyny oddziaływania artystycznego ukryte są w podświadomości, chociaż sygnalizuje, że poznanie podświadomości pozwala w znaczącym stopniu na zgłębienie danego zagadnienia. Sygnalizuje, iż takie stanowisko wprowadza sugestię o próbach poznawania czegoś znajdującego się poza naszą świadomością, a więc niepoznawalnego. I nawet, jeśli poznamy to co podświadome, a poprzez fakt poznania podświadomego, to podświadome przestanie być podświadomym i stanie się zjawiskiem ludzkiej psychiki, to i tak nie wytłumaczy się przeżyć estetycznych ludzi. Nauka bowiem bada nie tylko 
coś bezpośrednio danego i świadomego, ale także cały szereg zjawisk i faktów, które mogą być poznawane (poznane) drogą pośrednią, poprzez ślady, za pomocą rekonstrukcji i z wykorzystaniem materiału, który nie tylko jest zupełnie odmienny od badanego przedmiotu, lecz często okazuje się sam w sobie z zasady mylący i nieprawdziwy (s. 124-125).

Wygotski twierdzi, że podświadomość nie jest oddzielona od świadomości jakimś nierealnym, niezobiektywizowanym i nieprzekraczalnym murem. Powstające w niej procesy mają przecież swój dalszy ciąg w świadomości, i na odwrót: wiele spraw ze świadomości wypieramy w sferę podświadomości. Istnieje więc cały, ciągły i nieprzerwalny (nieprzerywany) ani na chwilę, żywy i dynamiczny związek pomiędzy obydwiema tymi sferami. Podświadomość wpływa na postępowanie ludzi, które ujawnia się w ich zachowaniu.A faktami obiektywnymi, w których podświadomość widziana jest najwyraźniej, są dzieła sztuki. $Z$ danych też względów wszelką świadomą i intelektualną interpretację, którą podaje artysta lub odbiorca sztuki należy uważać za pewną racjonalizację, ale z drugiej strony za pewne samooszukiwanie siebie, za usprawiedliwianie się przed sobą za interpretację wymyśloną post factum (1980, s. 125). Dlatego sztuka nie może być rozumiana na podstawie wąskiego kręgu życia jednostki, lecz wymaga również wyjaśnienia opartego na wszelkich zakresach życia społecznego w perspektywie historyczno-kulturowej, kulturowego transferu doświadczenia zbiorowości ludzkich i składającego się na te zbiorowości doświadczenia konkretnych ludzi z epok minionych, przyswojenia tego doświadczenia przez daną osobę oraz jego transformacji indywidualnej i zbiorowej wpisanej w aktualną sytuację osoby i zbiorowości, do której osoba ta przynależy (s. 143).

\section{Zagadnienie wieku kulturowego w poglądach Wygotskiego na rozwój dziecka ${ }^{3}$}

W rozważaniach na temat rozwoju kulturowego człowieka Wygotski wprowadza pojęcie wieku kulturowego, relatywnie do pojęcia wieku kalendarzowego, biologicznego, intelektualnego (wieku inteligencji). Mówiąc o wieku kulturowym stwierdza, iż w przypadku analizy zagadnienia wieku biologicznego czy wieku inteligencji na ogół nie tylko podkreśla się fakt obecności okresów rozwoju, które po sobie sukcesywnie następują, ale również określoną tendencję

${ }^{3}$ Przedstawione w tej części artykułu rozważania zostały przygotowane w oparciu o następującą publikację: Wygotski L.S. (2003). Problem wieku kulturowego. W: Psychologia rozwoju człowieka, Wydawnictwo „Smysł”, Moskwa, s. 520-532. 
niepokrywania się wieku biologicznego czy wieku inteligencji z wyznaczonymi standardami normy w postaci in plus lub in minus. Podobnie rzecz się ma rozwojem kulturowym.

Zdaniem autora rozwój kulturowy dziecka stanowi szczególny i specyficzny rodzaj rozwoju, polegającna przyswajaniu osiągnięć historyczno-kulturowego rozwoju ludzkości oraz kształtowaniu na tym tle własnych umiejętności i kompetencji kulturowych, niebędących w sprzeczności z przyjętymi przez społeczeństwo standardami. Rozwój kulturowy nie zawsze wpisuje się w korelacje z rozwojem biologicznym czy rozwojem intelektualnym, tak jak np. rozwój ruchowy nie zawsze jest tożsamy z rozwojem intelektualnym. Istnieją przecież $\mathrm{w}$ danym względzie określone różnice indywidualne. Dwoje dzieci (podobnie jak i dwie osoby dorosłe) w identycznym wieku kalendarzowym może prezentować odmienne, zróżnicowane i nieidentyczne rodzaje i poziomy rozwoju kulturowego, podobnie jak dwoje dzieci (dwie osoby dorosłe) w identycznym wieku kulturowym może posiadać różny wiek kalendarzowy i intelektualny.

Wygostki stoi na stanowisku, że rozwój kulturowy oraz łączący się z nim wiek kulturowy w znacznym stopniu determinują zdolności (zdolności ogólne, wybitne zdolności ogólne, zdolności kierunkowe, wysypkowe, szczególne), inteligencja oraz zasady i normy nabyte w czasie wychowania i kształcenia. Równocześnie podkreśla ich osobisty, zindywidualizowany charakter. Nie można do analizy rozwoju kulturowego podchodzić w sposób automatyczny, mechanicznie wskazując zależności rozwoju i wieku kulturowego z rozwojem i wiekiem intelektualnym oraz posiadanymi zdolnościami.

Na postawie badań naukowych zrealizowanych na zwierzętach (np. małpach) oraz badań dotyczących krytycznych analiz oceny ilorazu inteligencji, gdzie włączone do tej oceny komponenty posiadają nie tylko zróżnicowany poziom, odmienny zakres ocenianych umiejętności i funkcji, nieidentycznych i nietożsamych (w oparciu o które zatem dokonuje się ustalanie niesłusznej i niesprawiedliwej oceny globalnej), Wygotski stawia tezę o szkodliwości takiego rozumienia inteligencji człowieka i szkodliwości przenoszenia danego postępowania na ocenę rozwoju kulturowego. Przywoływane bowiem procesy, poza zindywidualizowanym, warunkowanym wieloczynnikowo (w tym osobowością) czy sytuacją społeczną posiadają również korelację z wyznacznikami ich plastyczności i kreatywności. Ludzie mogą przecież wykazywać wybitne zdolności, np. artystyczne w określonym zakresie i nie posiadać takich zdolności w innych zakresach, wchodzących w skład oceny rozwoju kulturowego. Rosyjski psychologi przywołuje przykład Lwa Tołstoja, który był wybitnym 
pisarzem, ale nie był wybitnym malarzem i szachistą. Nie neguje jednocześnie zależności pomiędzy wpływem zdolności na rozwój kulturowy i pomiędzy wpływem rozwoju kulturowego na zdolności.

Zdaniem Wygotskiego ludzie za przyczyną wychowania i kształcenia, na drodze kulturowego przekazu (poprzez transfer kulturowy), przyswajają nie tylko historyczno-kulturowy dorobek ludzkości, ale również przypisane (nadane) przez ludzkość znaczenia różnym zjawiskom, czynnościom, działaniom, zachowaniom, sposobom myślenia czy rozwiązywania pojawiających się problemów. Zatem odwzorowują je - zasadniczo automatycznie - w życiu własnym. Przykładem może być sposób rozwiązywania zadań matematycznych z niewidomą oznaczaną znakiem „X”. Jeśli więc określonej grupie uczniów takie zadanie zostanie zadane do wykonania, to większość z nich rozwiąże je prawidłowo. Jeżeli jednak znak „X” zostanie zastąpiony innym znakiem symbolicznym, np. literą lub znakiem graficznym, np. kreską, to jego rozwiązanie wywoła już poważne trudności i tylko część uczniów będzie w stanie wykonać je prawidłowo z szybkością identyczną, jak w przypadku stosowania znaku „x”, część wykona dane zadanie, ale w wolniejszym tempie, a część nie wykona takiego zadania w ogóle, mimo że w tradycyjnej postaci zrealizowała je bez większych problemów. Stąd wnioskuje, że o specyfice, istocie, jakości i poziomie rozwoju kulturowego człowieka decyduje umiejętność radzenia sobie w sytuacjach problematycznych, w sposób odmienny od wyznaczonych standardów nadanych danym sytuacjom w toku historyczno-kulturowego rozwoju ludzkości; nietradycyjny i kreatywny.

Relacje pomiędzy rozwojem kulturowym i zdolnościami w opinii Wygotskiego posiadają złożony charakter, złożoną strukturę. Z jednej strony rozwój kulturowy wykazuje tendencję do indywidualizacji określonych zakresów i form zdolności, z drugiej - do poszerzenia zakresów i form zdolności ze względu na niejednoznaczny i skomplikowany charakter zależności rozwoju kulturowego i rozwoju ogólnych zdolności. Wiek kulturowy można wobec powyższego rozumieć jako osiągnięty przez osobę (dziecko) poziom rozwoju kulturowego w relacji do wieku kalendarzowego i wieku inteligencji. Dlatego w ocenie rozwoju kulturowego i zdolności kulturowych człowieka należy postępować w sposób zbliżony jak w diagnozie medycznej. Lekarz, kiedy zgłasza się do niego pacjent bierze pod uwagę wszystkie sygnalizowane i możliwe do poznania parametry, np.: temperaturę jego ciała, dane $\mathrm{z}$ wykonanego zdjęcia rentgenowskiego, i inne, i na podstawie ich analizy oraz powiązania stawia diagnozę. Bowiem identyczna temperatura ciała, kaszel, ból gardła w różnych kombinacjach oznaczają różne schorzenia. Oceniając rozwój kulturowy należy 
mieć na względzie nie tylko przejawiane i poddawane ocenie jego komponenty, ale też ich wzajemne powiązania.

Znakomitym przykładem dla wyjaśnienia opisanych tendencji - w opinii Wygotskiego jest opanowanie mowy przez dziecko w wieku znajdujące się w okresie, kiedy umiejętność mowy i posługiwania się językiem ojczystym jest nabywana. Rozwój mowy u dziecka nie tylko zależy od poziomu i możliwości intelektualnych, uwarunkowań indywidualnych, środowiskowych, ale też od wzajemnych relacji pomiędzy tymi elementami. Na kolejnym etapie rozwoju dziecka, w wieku wczesnoszkolnym, poziom opanowania przez dziecko mowy wpływa na opanowanie umiejętności czytania i pisania. I mimo, że dziecko myśli w sposób konkretno-obrazowy, to przejawia swój sposób myślenia w formie słownej, tj. bardziej abstrakcyjnej. Mową w takich okolicznościach stymuluje rozwój myślenia, jest znaczącym determinantem na drodze przejścia do kolejnego etapu jego rozwoju. Jednocześnie rozwój myślenia determinuje rozwój mowy.

\section{Podsumowanie}

Lew S. Wygotski należy do grona tych znakomitych uczonych, psychologów, których poglądy na rozwój człowieka do dzisiaj pozostają aktualne. Koncepcja historyczno-kulturowego rozwoju ludzi, opinia na temat zależności pomiędzy rozwojem mowy i myślenia, poglądy co do niejednoznacznej, warunkowanej różnorodnymi czynnikami oraz korelacjami zależności pojawiających się ramach danych czynników w okolicznościach różnych sytuacji życia indywidualnego i społecznego stanowią obecnie nie tylko pewną propozycję związaną z możliwym myśleniem o rozwoju ludzi w ogóle, ale także mogą ukierunkowywać praktyczne działania w przestrzeni socjalizacji, kształcenia, wychowania, rozwoju kulturowego i kulturalnego.

Zrealizowane w tekście analizy koncentrują się zasadniczo na zagadnieniu rozwoju kulturalnego i kulturowego, ze szczególnym uwzględnieniem stanowiska Wygotskiego na temat ludzkiej kultury, sztuki i rozwoju kulturowego dziecka. Mogą też stanowić przyczynek do wyrobienia własnej opinii na temat słuszności, względnej słuszności czy nawet niesłuszności tez wypowiadanych przez tego autora w zakresie omawianej tematyki. 


\section{Bibliografia:}

Doroszewski W. (red.) (1980). Słownik poprawnej polszczyzny. Warszawa: PWN.

Dzierżanowski R. (1983). Słownik chronologiczny dziejów medycyny i farmacji. Warszawa: PZWL.

Leontiew A.N. (2003). Wprowadzenie. W: Wygotski L.S. Psychologia rozwoju człowieka. Moskwa: Wydawnictwo „Smysł”, s. 5-17.

Lifanowa T.M. (2003). Życie i twórczość L.S. Wygotskiego. W: L. Wygotski, Podstawy defektologii. Sankt-Petersburg-Moskwa-Krasnodar: Wydawnictwo „Łań”, s. 3-21.

Tokarski J. (red.) (1978). Słownik wyrazów obcych. Warszawa: PWN.

Ulotka (2016). 120-ta rocznica urodzin Lwa Siemionowicza Wygotskiego, Moskwa: MPGU.

Wygotski L.S. (1980). Psychologia sztuki. Kraków: Wydawnictwo Literackie.

Wygotski L.S. (1989). Myślenie i mowa. Warszawa: PWN.

Wygotski L.S. (2003). Problem wieku kulturowego. W: Wygotski L. S. Psychologia rozwoju człowieka. Moskwa: Wydawnictwo „Smysł”, s. 520-532.

Wygotski L.S. (2003). Psychologia rozwoju dziecka. Moskwa: Wydawnictwo „Smysł”.

Zaorska M. (2008). Lew S. Wygotski o wychowaniu dzieci głuchoniewidomych. CzłowiekNiepetnosprawność - Społeczeństwo, nr 2(8), Warszawa: APS, s. 7-16.

Zaorska M. (2012). Rozwój kulturowy dziecka w koncepcji L.S. Wygotskiego. Acta Universitatis Nicolai Copernici. Pedagogika XXVIII, s. 29-48. 